\title{
Effects of Accelerated Aging on Soybean Seed Germination Indexes at Laboratory Conditions
}

\author{
Zahra RASTEGAR, Mohammad SEDGHI*, Saeid KHOMARI \\ University of Mohaghegh Ardabili, Faculty of Agriculture, Department of Agronomy and Plant Breeding, \\ Ardabil,Iran;z_rastegar@ymail.com,mosedghi2003@yahoo.com (*correspondingauthor)
}

\begin{abstract}
Reduction of seedling growth is a consequence of seed deterioration. An experiment was conducted to evaluate the effects of duration of seed aging on soybean seed germination characteristics. Experiment conducted as completely randomized design with 4 replications. The seeds of 'DPX' line of soybean with $15-16 \%$ moisture were incubated for $3,7,10,14,17$ day at $40^{\circ} \mathrm{C}$ in sealed containers for ageing treatment and non aged seeds were considered as control. Results showed that rapid aging treatment has a significant effect on studied parameters. Germination percent (GP), means of daily germination (MDG), means time to germination (MTG), coefficient of velocity of germination (CVG) and germination index (GI) decrease significantly. Also, germination uniformity (GU) was affected by deterioration time. Abnormal seedling $(\mathrm{ABS})$ percentage increased. Results shows that rapid aging experiment could be a useful test for determine soybean seed quality.
\end{abstract}

Keywords: aging, deterioration, germination, laboratory, seed, soybean

\section{Introduction}

After harvesting several field crops seeds keep in storage conditions for some days, weeks, months or years. Seed storage conditions can determine germination characteristics and vigor potential of seeds (Mc Donald, 1999). Various factors such as weather conditions during seed producing stage, pests and diseases, seed oil and moisture content, mechanical damages, storage time and relative humidity of store can affect vigour of seeds (Krishnan et al., 2003; Marshal and Levis, 2004). Seed aging is a function not only of time but also of temperature and moisture (Ellis and Roberts, 1981). Consequently the seed storage environment greatly influences the period of seed survival (Ellis et al., 1982).

Seed deterioration can be defined as the loss of quality, viability and vigour either due to aging or effect of adverse environmental factors. The rate of deterioration rapidly increases in either seed moisture content or temperature of storage (Kapoor et al., 2010).

Decrease in seed vigour is due to decrease in seed quality, percentage, rate of germination and yield and also can increase susceptibility to environmental stress (Tekrony et al., 1989). Rising of temperature, humidity and oxygen pressure could cause structural damages on DNA and ribosomal RNA, increasing enzyme activity, respiration and membrane permeability (Mc Donald, 1999).

Oxidative damages are responsible for the deterioration changes observed in aged seeds. Free radical oxidations, enzymic dehydrogenation and aldehyde oxidation of proteins might reasonably contribute to the progress of seed quality (Ghassemi-Golezani et al., 2010). Woodstock and Tylorson (1981) state that deterioration during accelerated aging of soybean seeds involves an imbalance between glycolysis and tricarboxylic acid cycle, as evidenced by high levels of ethanol and acetaldehyde during imbibitions and this imbalance is more pronounce than, that which occurs during the imbibitions of vigorous no deteriorated seeds. Also, Mc Donald (1999) state that seed deterioration leads to reductions in seed quality, performance and stand establishment.

Today these tests are one of the most successful tests for seed vigor and have a good correlation to field emergence (TeKrony et al., 1989). Gutierrez et al. (1993) by working on seed deterioration of different corn genotypes observed that seed viability, vigour, and percent of emerged seed sand decreased mainly with increasing in deterioration levels. Decrease in seed vigour as affected by deterioration was proven in mungbean (Bishnoi and Santose, 1996) and chickpea seeds (Dahiya et al., 1997).

Present study was conducted in order to evaluate various germination indexes during different duration as a result of rapid aging test.

\section{Material and methods}

Soybean seeds (cv. 'DPX') were obtained from Institute of Oil Seed Cultivation, Gorgan, Iran. According to accelerated aging method to create seed lots of different vigour, seeds were incubated in sealed containers at $40^{\circ} \mathrm{C}$ for $0,3,7,10,14,17$ days (seed primary moisture content was 15-16 percent and kept in packages) (Copland 
and Mc Donald, 1995). Seeds were sterilized with $0.5 \%$ of sodium hypochlorite before germination test performing. For standard germination test 50 seeds with 4 replications put in 2 layers of paper towel and placed in germination chamber at $25 \pm 1^{\circ} \mathrm{C}$ for 8 days (Anonymous, 2010) in a completely randomized design arrangement. After test time expiration, some germination indexes correlating to seed vigour were evaluated such as: germination percent (GP), germination uniformity (GU), normal and abnormal seedling $(\mathrm{ABS})$ according to international seed testing association (ISTA), means time to germination (MTG), means daily germination (MDG), coefficient of velocity of germination (CVG) and germination index (GI) were evaluated by daily count as below:

1. Means time to germination is an index for germination rate (Ellis and Roberts, 1981).

$$
\mathrm{MTG}=\frac{\sum(n d)}{\sum n} \quad\left(\text { day }^{-1}\right)
$$

where ' $n$ ' is number of germinated seeds in day d, $\Sigma \mathrm{n}$ is total germinated seeds, D day of counting.

2. Means daily germination is an index of daily germination rate (Scott, 1984).

$$
\mathrm{MDG}=\frac{F G P}{D}
$$

FGP is final germination percent, $\mathrm{D}$ is day of maximum germination (experiment period).

3. Coefficient of velocity of germination is an index for germination speed (Maguire, 1962).

$$
\mathrm{CVG}=\frac{G 1+G 2+\ldots+G n}{(1 X G 1)+(2 X G 2)+\ldots+(n X G n)}\left(\text { seed day }{ }^{-1}\right)
$$

$\mathrm{G}$, is number of germinated seeds

4. Germination index.

$\mathrm{G} . \mathrm{I}=\frac{n}{d}$

' $n$ ' number of emerged seeds in day d, d is day after planting (Abdul-Baki and Anderson, 1973).
For calculating velocity of germination and germination uniformity (difference between times to 10 percent of germination to 90 percent of germination) GERMIN program was used (Soltani et al., 2006). Data were analyzed with SAS (statistical analysis system) software and regression diagram of aging duration and means of normal seedling percent evaluated with simple linear regression analysis.

\section{Results}

Tab. 1 represent a summary of the analysis of variance (ANOVA) for seed germination characteristics. Seed deterioration had significant effects on seed germination traits at the $\mathrm{P}<0.01$ of probability, except of GU. It was significant at $\mathrm{P}<0.05$ of probability. GP decreased significantly $(\mathrm{P}<0.01)$ as affected by deterioration levels according to Tab. 1.

Deterioration time affected D10 and D90 and time to beginning and ending of germination. These parameters directly affected GU. Longer seed exposing to $40^{\circ} \mathrm{C}$ decreased germination uniformity significantly $(\mathrm{P}<0.05)$. Germination index (GI) decreased significantly $(\mathrm{P}<0.01)$ with increasing deterioration time (Tab. 1).

Results indicated that coefficient of velocity of germination (CVG) decreased with increasing deterioration period (Tab. 2). Control treatment (without deterioration) had the highest germination speed. Means daily germination (MDG) decreased in aged seeds but by the results, means time to germination (MTG) increased in these seeds, it shows the adverse effect of deterioration on soybean seed and susceptibility of soybean seed quality. The abnormal seedlings (ABS) increased significantly in highest level of deterioration times.

Results showed that after 17 days of deterioration, GP had the lowest value. Fig. 1 represents the effect of seed aging on GP that significantly affected by seed deteriora-

Tab. 1. Analysis of variance for deterioration effect on soybean seeds germination indexes

\begin{tabular}{ccccccccc}
\hline S.O.V & DF & GP & GU & GI & CVG & MDG & MTG & ABS \\
\hline Deterioration time & 5 & $0.0033^{*}$ & $2.1^{*}$ & $259.8^{* *}$ & $0.003^{*}$ & $0.708^{* *}$ & $1.17^{*}$ & $0.135^{*}$ \\
Error & 15 & 0.0001 & 0.57 & 1.36 & 0.0001 & 0.005 & 0.035 & 0.003 \\
CV & & 2.31 & 9.2 & 11.16 & 4.7 & 8.9 & 3.9 & 27.21 \\
\hline
\end{tabular}

${ }^{*}$ and ${ }^{* *}$ significant difference at $\mathrm{P}<0.05$ and 0.01 ; Germination percent=GP; germination uniformity=GU; germination index=GI; coefficient of velocity of

\begin{tabular}{|c|c|c|c|c|c|c|c|}
\hline S.O.V & GP $(\%)$ & $\mathrm{GU}$ & GI & CVG (seed day $\left.{ }^{-1}\right)$ & MDG & MTG $\left(\right.$ day $\left.^{-1}\right)$ & $\mathrm{ABS}$ \\
\hline Control & $94^{a}$ & $9.3^{\mathrm{a}}$ & $21.4^{a}$ & $0.26^{a}$ & $1.19^{a}$ & $3.7^{\mathrm{d}}$ & $21.5^{d}$ \\
\hline 3 days & $65^{\mathrm{b}}$ & $8.4^{\mathrm{ab}}$ & $14.9^{\mathrm{b}}$ & $0.26^{\mathrm{a}}$ & $1.13^{\mathrm{b}}$ & $4.6^{c}$ & $32.9^{c}$ \\
\hline 7 days & $64^{\mathrm{b}}$ & $8.2^{b}$ & $15.9^{b}$ & $0.21^{\mathrm{b}}$ & $1.08^{b}$ & $4.9^{c}$ & $46.25^{b}$ \\
\hline 10 days & $64^{\mathrm{b}}$ & $8.1^{b}$ & $5.7^{c}$ & $0.20^{\mathrm{b}}$ & $0.77^{\mathrm{c}}$ & $4.9^{c}$ & $46.9^{b}$ \\
\hline 14 days & $52^{c}$ & $7.1^{\mathrm{c}}$ & $1.4^{\mathrm{c}}$ & $0.18^{c}$ & $0.20^{c}$ & $5.1^{b}$ & $46.25^{b}$ \\
\hline 17 days & $42^{\mathrm{d}}$ & $7.9^{c}$ & $3.27^{\mathrm{d}}$ & $0.19^{c}$ & $0.49^{\mathrm{d}}$ & $6.2^{\mathrm{a}}$ & $58.2^{\mathrm{a}}$ \\
\hline
\end{tabular}
germination=CVG; Means daily germination=MDG; Means time to germination=MTG; Abnormal seedlings=ABS

Tab. 2. Means comparison of germination indexes as affected by deterioration time in soybean seeds

Means in each column with same letters are not different significantly; Germination percent=GP; Germination uniformity=GU; Germination index=GI; Coefficient of velocity of germination=CVG; Means daily germination=MDG; Means time to germination=MTG; Abnormal seedlings=ABS 
128

tion in a quadratic regression model. It is showing that by increasing aging time, GP decreases significantly. tics such as: germination percentage, germination uniformity and germination index. Deterioration time increased the percent of abnormal germinated seeds and mean time

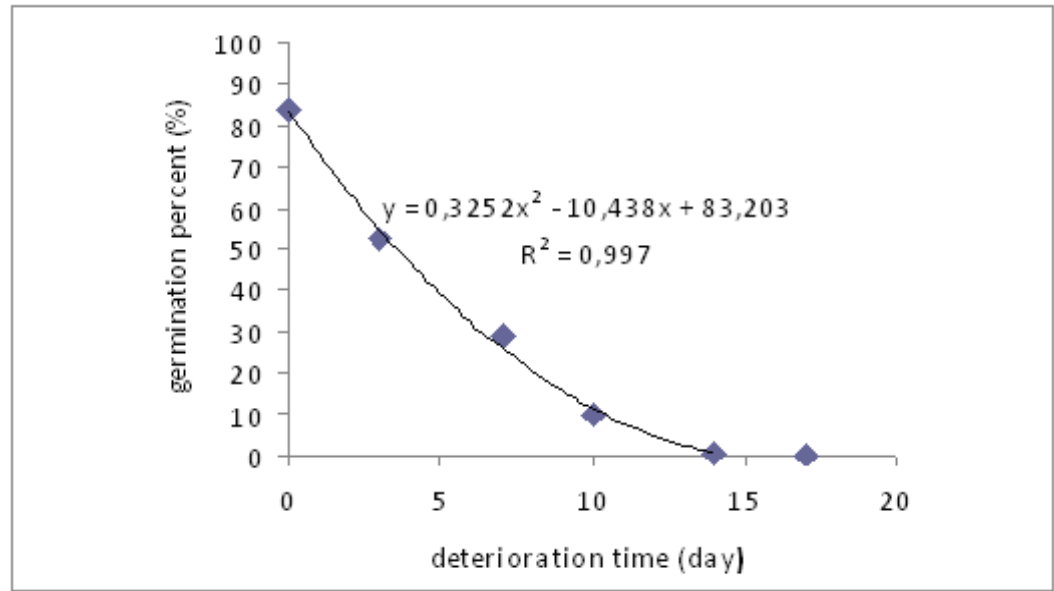

Fig. 1. Decrease in germination percent of soybean seeds with increasing deterioration time

\section{Discussion}

The evidence provided here indicates that deterioration treatment caused a remarkable decrease in germination characteristics. These results agree those of Ruzrokh et al. (2003) and Verma et al. (2003). Failure of aged seeds to germinate might be due to lipid proxidation, mitochondrial dysfunction and less ATP production (Mc Donald, 1999). Ghassemi-Golezani et al. (2010) reported that decrease in germination percent and other indexes can be related to physiological and biochemical changes during seed aging. The processes during aging, decreases plasma membrane sustainability, changes in molecular structure of nucleic acid, decreases in enzyme activities during seed senescence and increases time for fast germination (Justice and Bass, 1979). Studies of Kapoor et al. (2010) showed that accelerated aging in cowpea seeds affected all physiological parameters such as germination percentage and vigour index. Their findings also supported that decrease in seed viability, germination rate and vigour is correlated with biochemical changes (decrease soluble proteins and sugar content) associated with seed aging. Mean time to germination increased in deteriorated seeds in our study. It is in agreement with the results of Khaje Hoseini $e t$ al. (2003). They showed that soybean deteriorated seeds took long time to germinate. Rehman et al. (1999) showed that germination percent and germination speed decreased significantly in acasia's seed by deterioration in contrast to control. Lanteri et al. (1996) show that less deteriorated pepper seed caused shortening of mean time of germination in compare with unaged seeds.

\section{Conclusions}

Overall, the results obtained in this study show that seed aging reduces all the studied germination characteris- to germination. In addition, coefficients of velocity of germination and mean daily germination were the lowest in 17 days after beginning of deterioration. According to these observations it is necessary to kept seeds out of deterioration conditions to achieve vigorous seedlings with the highest uniformity in emergence.

\section{Acknowledgements}

Authors are sincerely thankful to seed physiology and technology laboratory for providing lab facilities for the current project.

\section{References}

Abdul-Baki AA, Anderson JD (1973). Vigor determination in soybean by multiple criteria. J Crop Sci 13:630-633.

Anonymous (2010). International rules for seed testing. International seed testing association (ISTA). Switzerland.

Bishnoi U, Santose R (1996). Evaluation of seed of three murgbeen cultivar for storability and field performance. J Seed Sci Thechnol 24:237-243.

Copland LO, Mc Donald MB (1995). Principles of seed science and technology. Chapman and Hall, New York, USA.

Dahiya OS, Tomer RPS, Kumar S (1997). Evaluation of viability and vigor parameters with respect to field emergence in chick pea (Cicer arietinum L.). J Seed Res 25:1019-1024.

Ellis RH, Roberts EH (1981). The quantification of ageing and survival in orthodox seeds. J Seed Sci Technol 9:377-409.

Ellis RH, Osei-Bonsu EE, Roberts EH (1982). The influence of genotype, temperature and moisture on seed longevity in chickpea, cowpea and soybean. J Annul Bot 50:69-82.

Ghassemi-Golezani K, Khomari S, Dalili B, HosseinzadehMahootchy B, Chadordooz-Jedi A (2010). Effect of seed aging on field performance of winter oil seed rape. J Food Agric Envir 8(1):175-178. 
Gutierrez G, Gruz F, Moreno J, Gonzalez-Hernandez VA, Vaz quez-Ramos JJ (1993). Natural and artificial seed ageing in maize germination and DNA synthesis. J Seed Sci Res $3: 279-285$.

Justice OL, Bass LN (1979). Principles and practices of seed storage. Castle House, Pub London.

Kapoor N, Arya A, Siddiqui MA, Amir A, Kumar H (2010). Seed deterioration in chickpea (Cicer arietinum L.) under accelerated aging. Asian J Plant Sci 9(3):158-162.

Khaje-Hoseini M, Powell AA, Bingham IJ (2003). The interaction between salinity stress and seed vigour during germination of soybean seeds. J Seed Sci Technol 31:715725 .

Krishnan P, Nagarajan S, Dadlani M, Moharir AV (2003). Characterization of wheat (Triticum aestivum L.) and soybean (Glycine max L.) seed under accelerated aging condition bye proton nuclear magnetic spectroscopy. J Seed Sci Technol 31:541-550.

Lanteri S, Nada E, Belletti E, Quagliott L, Bino RJ (1996). Effects of controlled deterioration and osmoconditioning on germination and nuclear replication in seeds of pepper (Capsicum annuum L.). J Annal Bot 77:591-597.

Mc Donald MB (1999). Seed deterioration: Physiology, repair and assessment. J Seed Sci Technol 27:177-273.

Maguire JD (1962). Seed of germination - aid in selection and evaluation for seedling emergence and vigour. J Crop Sci 2:176-177.
Marshal AH, Levis DN (2004). Influence of seed storage conditions on seedling emergence, seedling growth and dry matter production of temperate forage grasses. J Seed Sci Technol 32:493-501.

Rehman S, Harris PLC, Bourne WF (1999). Effect of artificial ageing on germination, ion leakage and salinity tolerance of Acacia tortilis and A. Coriaceae seeds. J Seed Sci Technol 27:141-149.

Ruzrokh M, Golozani KG, Javanshir A (2003). Relation between seed vigour with growth and yield in pea (Cicer arientum L.). Nahal o Bazr 18:156-169.

Scott SJ, Jones RA, Williams WA (1984). Review of data analysis methods for seed germination. J Crop Sci 24:1192-1199.

Soltani A, Golipoor M, Zeinali E (2006). Seed reserve utilization and seedling growth of wheat as affected by drought and salinity. J Environ Exp Bot 55:195-200.

TeKrony DM, Egli DB, Wickham DA (1989). Corn seed vigour effect on notillage field performance. J Crop Sci 29:1523 1528.

Verma SS, Verma U, Tomer RPS (2003). Studies on seed quality parameters in deteriorating seeds in Brassica (Brassica compestris). J Seed Sci Technol 31:389-396.

Woodstock LW, Taylorson RB (1981). Ethanol and acetaldehyde in imbibing soybean seeds in relation to deterioration. J Plant Physiol 67:424-428. 